\title{
SYNTHESIS, SPECTRAL, THERMAL DECOMPOSITION, KINETIC AND ANTIMICROBIAL STUDIES OF AZO-SCHIFF BASES
}

\author{
Hamid Hussein Eissa \\ Chemistry Department, Applied College Sciences, University of Hajah, Yemen \\ Email: hamedesia2003@yahoo.com
}

\begin{abstract}
In this work we focused on the synthesis of new Azo-Schiff bases which were prepared by condensation of 3-formyl-4-hydroxy phenylazo benzene with both 1,4-Bis (3aminopropyl) piprazine, thiocarbohydazide respectively. The Schiff bases were analyzed by different spectral techniques (LC-MS, GC-MS, 1H-NMR, IR). The new Azo-Schiff Bases were studied for antibacterial activities against gram positive (Bacillus subtilis and Staphylococcus aureus) and gram negative (Salmonella typhi and Escherichia coli) agents. The azo compound ligand exhibited a variable activity of inhibition on the growth of the bacteria. The compounds were subjected to simultaneous thermogravimetric analysis to study their decomposition mechanism and thermal stability.
\end{abstract}

Keywords: Azo Schiff Base, 3-formyl-4-hydroxy Phenylazo Benzene, Spectral Techniques, Antibacterial Activity, Thermogravimetric Analysis.

\section{INTRODUCTION}

Schiff bases are compounds which are prepared by the condensation of aldehyde or ketone with primary amines [1-3]. They are used in the synthesis of some industrial, bioactive and inorganic compounds [4-5]. The compounds generally show good fungicidal [6], Anticancer [7-9], antibacterial [10-12], antifungal [13,14], antiinflammatory [15-17] and herbicidal properties [18]. Azo compounds are widely used as dyes and pigments. Another application is analytical chemistry. On the other hand azo compounds show biological activities if it contains antibacterial [18] Schiff bases and thereby azo compounds are important structures in the medicinal and pharmaceutical fields [19]. Azo compounds, with two phenyl rings separated by an azo $(-\mathrm{N}=\mathrm{N}-)$ bond, are versatile molecules and have received much attention in research areas both fundamental and applied [20]. The strong electronic absorption maximum can be tailored by ring substitution to fall anywhere from the ultraviolet to red-visible regions, allowing chemical fine-tuning of color [20]. This, combined with the fact that these azo groups are relatively robust and chemically stable, has prompted extensive study of azobenzene-based structures as dyes and colorants. Furthermore, the light-induced interconversion allows systems incorporating azo group to be used as photo switches, effecting rapid and reversible control over a variety of chemical, mechanical, electronic and optical properties [21].

Recently heterocyclic azo compounds have been used in the Mitsunobu reaction [22]. Usually, azo compounds were synthesized by diazotization of the amine in mineral acid at 
about $0^{\circ} \mathrm{C}$ [22-26]. Schiff bases are used as substrates in the preparation of a large amount of bioactive and industrial compounds [27-31]. Azo compounds have a great biological activity as well as industrial importance $[32,33]$. The interaction of metal complexes with biological systems, the field of biocoordination chemistry, is receiving an increasing interest in recent days [34].

\section{EXPERIMENTAL}

\subsection{MATERIALS AND METHODS}

Ethanol, dimethyl formamide, salicylaldehyde, aniline, 1,4-[Bis(3-aminopropyl)] piprazine, thiocarbohydazide, Nutrient gar, Filter paper discs (Whatman No.1 filter paper, $5 \mathrm{~mm}$ diameter) were obtained from Sigma Aldrich Company. IR spectra were recorded on Jasco 300 FT-IR Spectrometer using compressed $\mathrm{KBr}$ discs. Mass spectra of the compounds were measured on a micro mass Quattro LCMS/MS, GC-MS/MS Spectrometer. ${ }^{1} \mathrm{H}$ NMR spectra were recorded at ambient Bruker DT-400 Spectrometer using $\mathrm{CDCl}_{3}$ with DMSO- DMF as the internal standard, M.P Apparatus Digital $\left(32-300^{\circ} \mathrm{C}\right)$. The thermogravimetric analysis (TGA) was carried out in a dynamic nitrogen atmosphere (20 $\left.\mathrm{mL} \cdot \mathrm{min}^{-1}\right)$, with a heating rate of $10^{\circ} \mathrm{C} \mathrm{min}^{-1}$ using Shimadzu TGA-50H thermal analyzer.

\subsection{SYNTHESIS OF SCHIFF BASES}

\subsubsection{Synthesis of 3-formyl-4-hydroxy phenylazo benzene (scheme 1)}

Azoaldehyde was prepared from aniline and 2hydroxy benzaldehyde in aqueous medium at $0-5^{\circ} \mathrm{C}$ according to a reported method and was purified by recrystallization from warm 95\% ethanol [35].

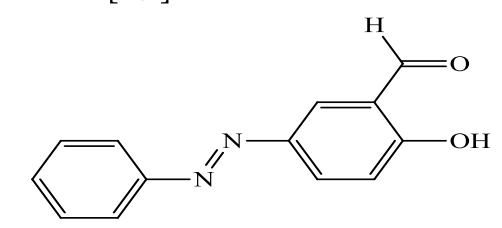

Scheme 13-formyl-4-hydroxy phenylazo benzene
2.2.2 Synthesis of Bis-N-[(5-phenylazo-2-hydroxy1-benzylidine)- 1,4-Bis(3-aminopropyl)] piprazine (I) Scheme (2)

Azo-coupled precursors were prepared as described previously [35] was added (0.01 $\mathrm{mol}$ ) to 3-formyl-4-hydroxy phenylazo benzene in $30 \mathrm{ml}$ from absolute ethanol to 1,4-Bis(3-aminopropyl)] piprazine, (0.005 mol) in $60 \mathrm{ml}$ ethanol, The reaction mixture was refluxed for 2 hour with continued stirring. A solid mass was formed in hot. The reaction mixture was allowed to cool to room temperature, it was suction filtered and recrystallized from suitable solvent, then dried in vacuum.

Orange; Yield: $(75 \%), \mathrm{m} . \mathrm{p}=227-228^{\circ} \mathrm{C}$, Empirical formula: $\left(\mathrm{C}_{36} \mathrm{H}_{40} \mathrm{~N}_{8} \mathrm{O}_{2}\right), M$. Wt: (616).

Mass spectrum (m/z): 616 (Fig.1.).

UV-Vis: $\lambda_{\max }=355 \mathrm{~nm}$ (Fig.2.).

IR ( $\mathrm{KBr}$ disk): $3417.86-3475.73 \mathrm{~cm}^{-1}(\mathrm{O}-\mathrm{H})$, 3039.81-3037.68 $\mathrm{cm}^{-1} \quad$ (C-H), aromatic), 2812.21-2935.66 $\mathrm{cm}^{-1} \quad(\mathrm{C}-\mathrm{H})$, aliphatic), $1635.64 \mathrm{~cm}^{-1} \quad(\mathrm{C}=\mathrm{N}), 1585.49 \mathrm{~cm}^{-1}(\mathrm{C}=\mathrm{C}$, aromatic), $1473.62-1496.76 \mathrm{~cm}^{-1} \quad(-\mathrm{N}=\mathrm{N}-)$, $1284.59 \mathrm{~cm}^{-1}$ (C-O), phenolic) (Fig.3.).

${ }^{1} \mathrm{H}-\mathrm{NMR}\left(\mathrm{CDCl}_{3}-400 \mathrm{MHz}\right) \delta=14.28(\mathrm{~s}, 2 \mathrm{H}$, $\mathrm{OH}), 8.449(\mathrm{~s}, 2 \mathrm{H}, \mathrm{CH}=\mathrm{N}), 7.054-8.021(\mathrm{~m}$, $16 \mathrm{H}, \mathrm{Ar}), \quad 3.704-3.736\left(\mathrm{t}, 4 \mathrm{H}-\mathrm{CH}_{2}-\mathrm{N}=\right)$, 2.317-2.520 (t, 4H,-N-CH $\left.2_{2}\right), 1.710-1.979(t$, $\left.4 \mathrm{H},-\mathrm{CH}_{2}-\right)$ (Fig.4.).

Elemental analysis: $\mathrm{C}_{31} \mathrm{H}_{23} \mathrm{~N}_{7} \mathrm{O}_{2}$, Calculated (\%): C: 70.11; H: 6.54, N: 18.17; O: 5.19 Found (\%) C: 70.12, H: 6.49, N: 18.20, O: 5.19 .

2.2.3 Synthesis of Bis-N-(5-phenylazo-2-hydroxy1- benzylidine)-thiocarbohydazide (11) Scheme (3)

Azo-coupled precursors were prepared as described previously [35] was added (0.01 mol) of 3-formyl-4-hydroxy phenyl azo benzene in $30 \mathrm{ml}$ from absolute ethanol tohiocarbohydazide $(0.005 \mathrm{~mol})$ in $60 \mathrm{ml}$ ethanol. The reaction mixture was refluxed 


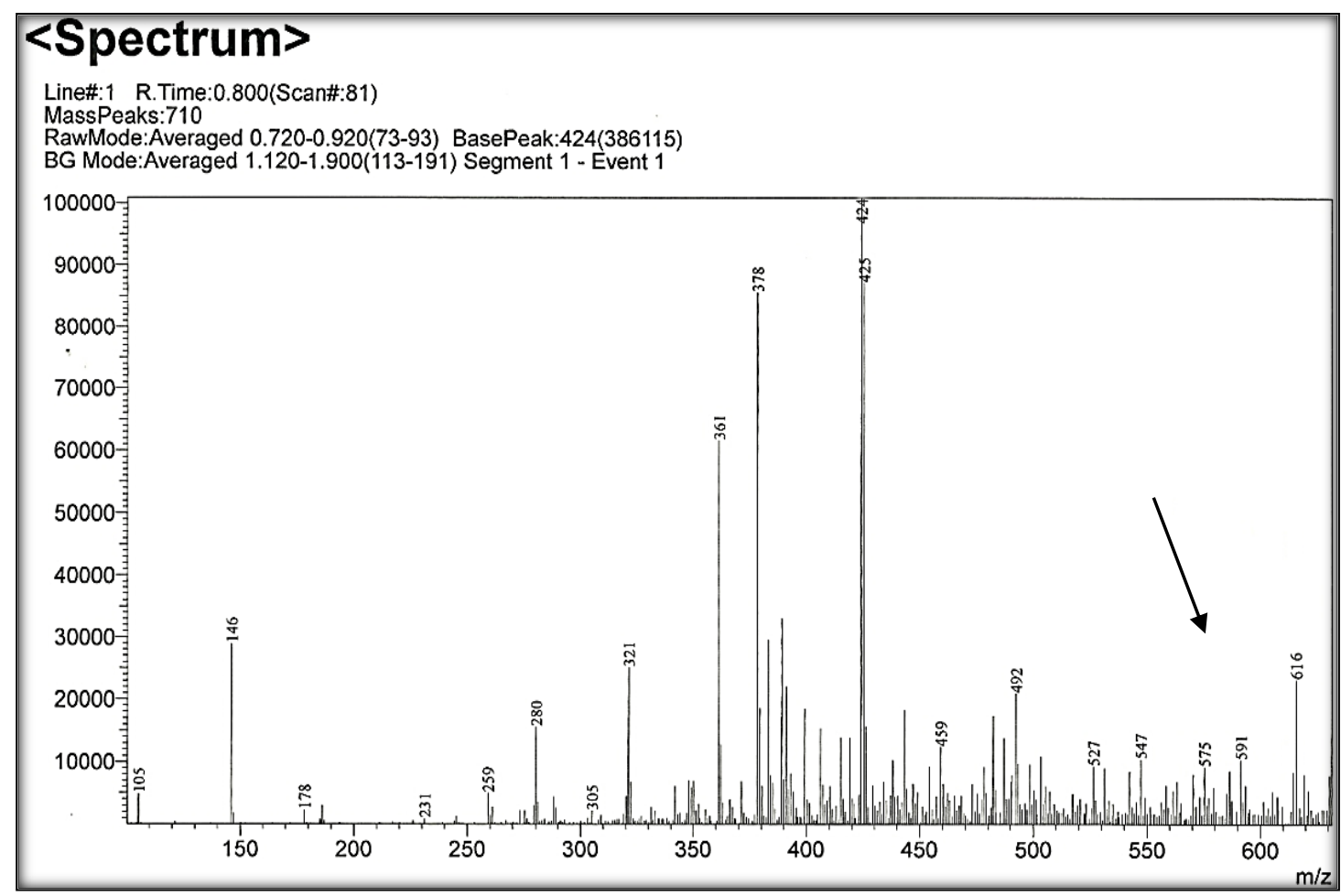

Fig.1. MS spectrum of Azo-Schiff base (I)

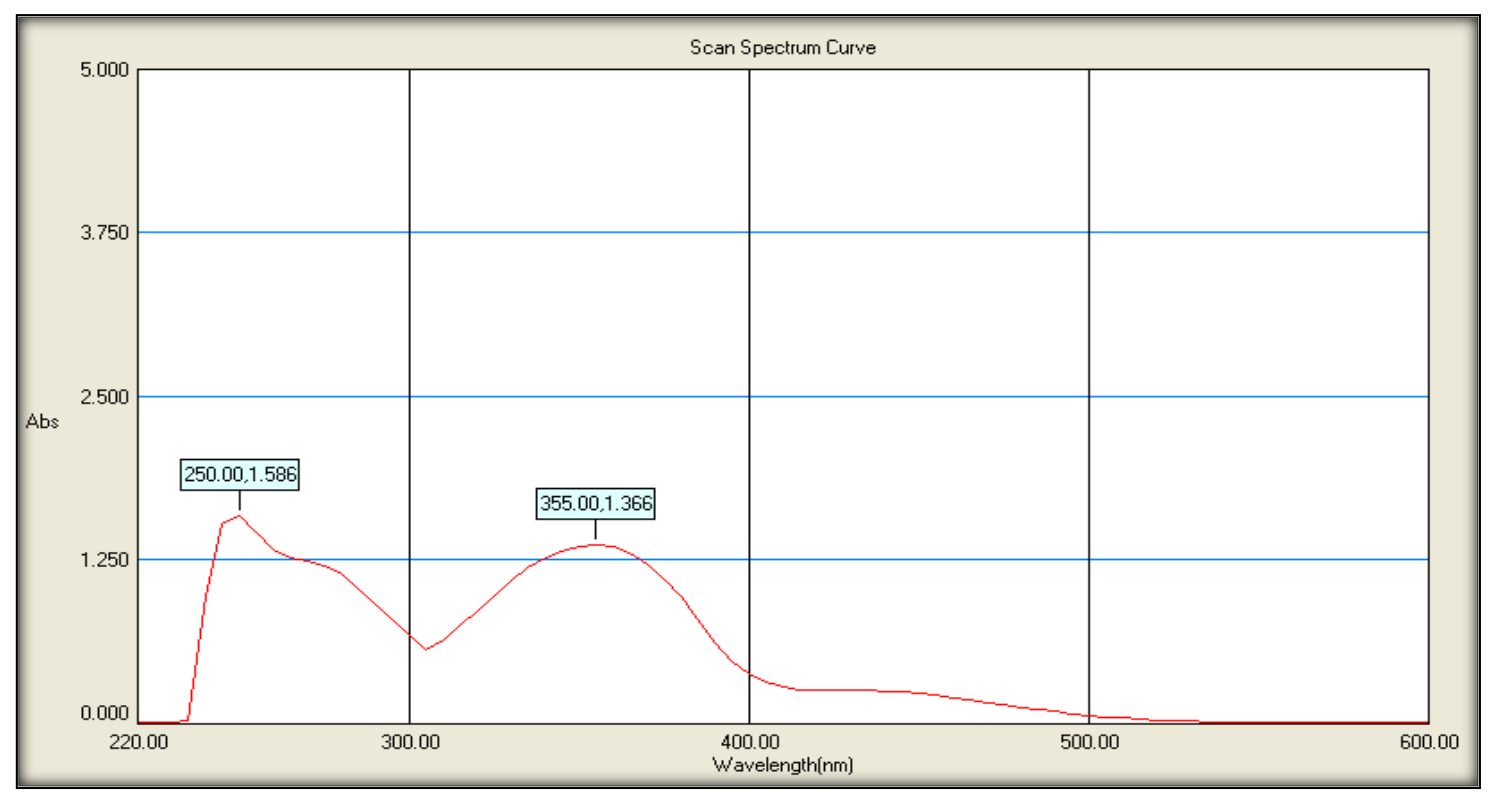

Fig.2. UV spectrum of Azo Schiff base (I) 


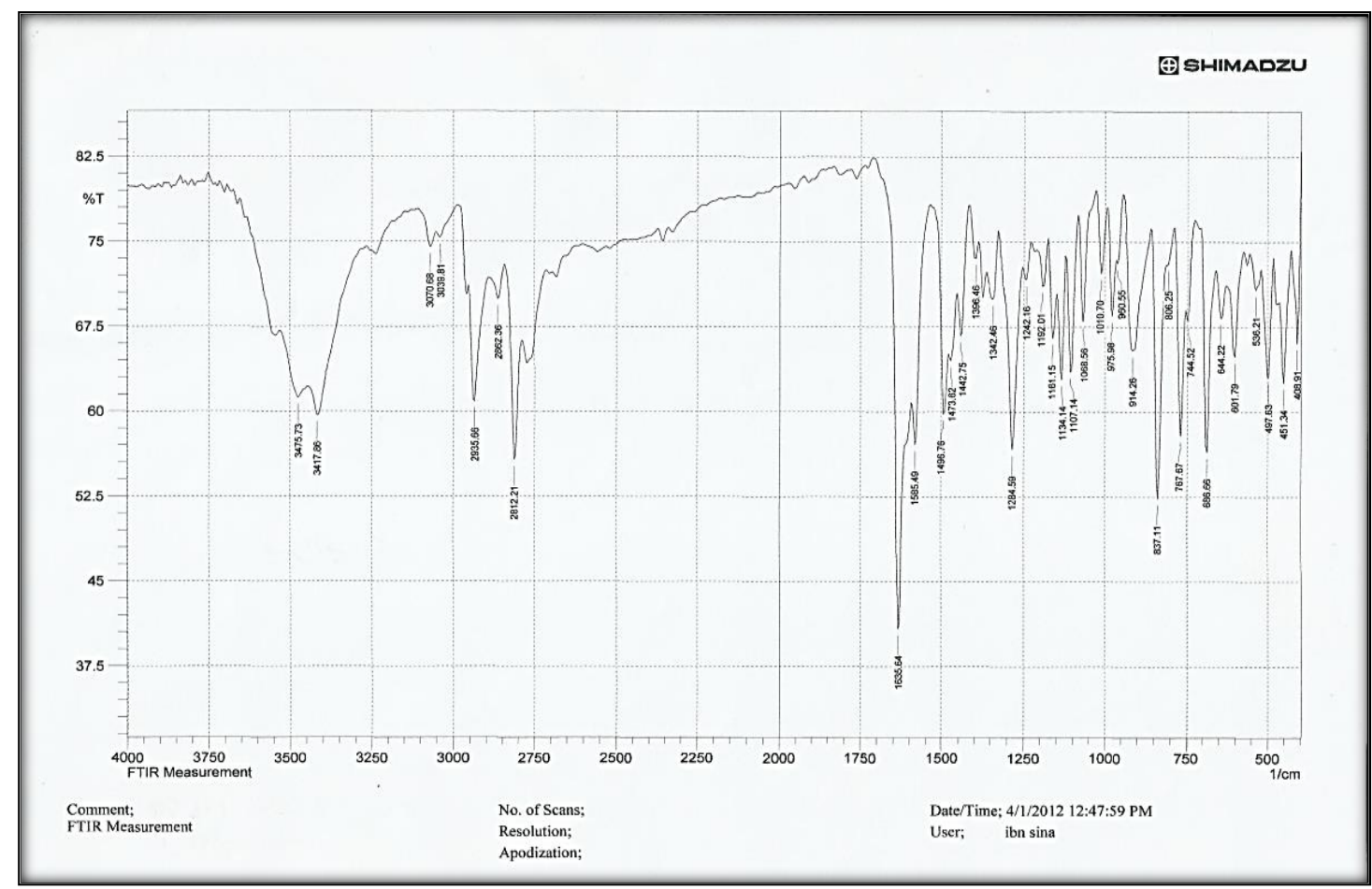

Fig.3. IR spectrum of Azo-Schiff ba se(I)

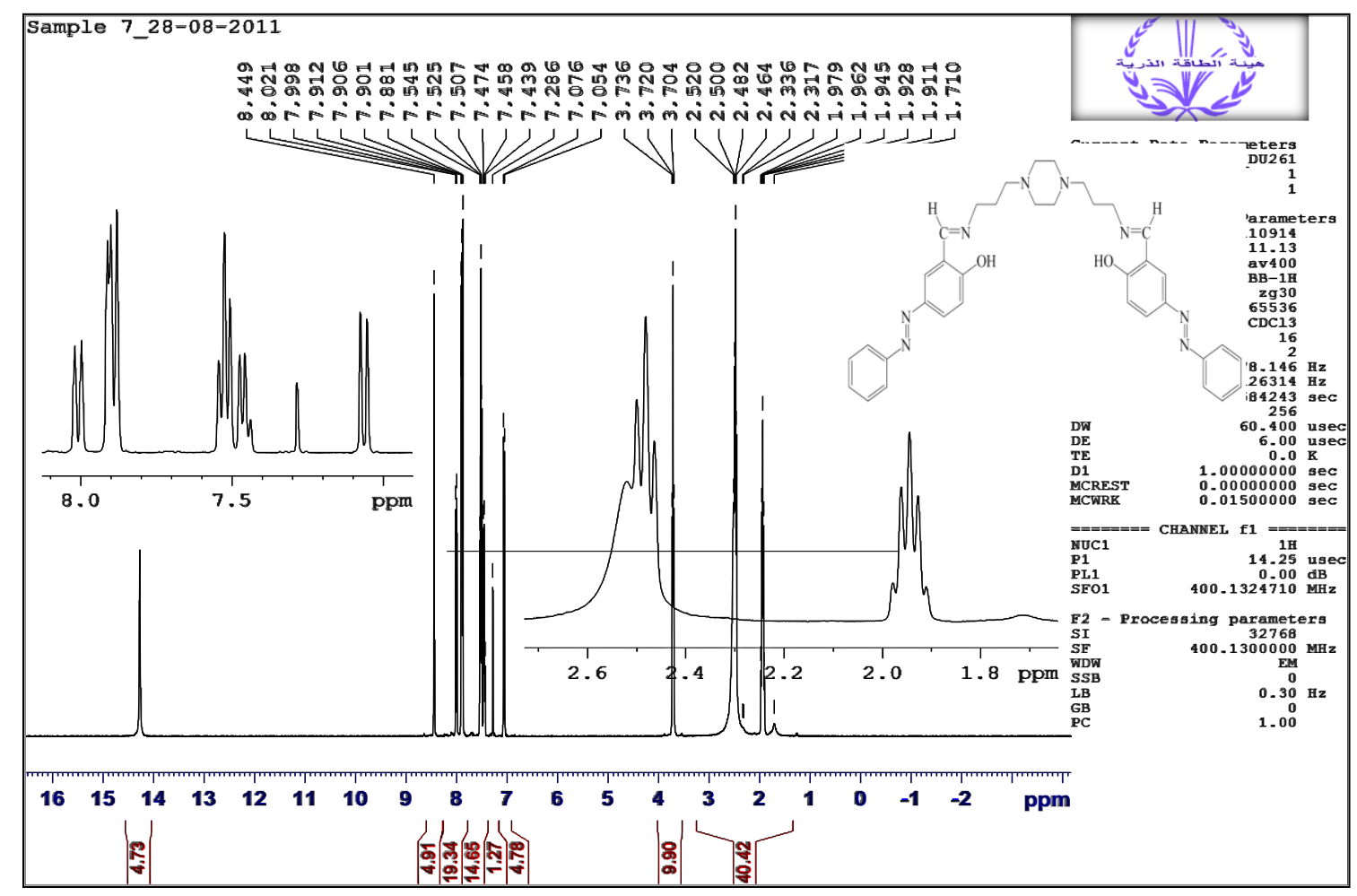

Fig.4. 1HNMR spectrum of Azo-Schiff base (I) 
for 2 hour with continue stirrer. A solid mass formatted on hot. The reaction mixture was allowed to cool room temperature, it was suction filtered and recrystallized from suitable solvent, then dried in vacuum $[36,37]$ Yellow; Yield: $\quad(75 \%), \quad$ m.p $=238^{\circ} \mathrm{C}$. Empirical formula : $\left(\mathrm{C}_{27} \mathrm{H}_{22} \mathrm{~N}_{8} \mathrm{O}_{2} \mathrm{~S}\right)$.

M.Wt:(522 g ).

Mass spectrum (m/z):522 (Fig.5.).

UV-Vis: $\lambda_{\max }=355 \mathrm{~nm}$ (Fig.6.).

IR ( $\mathrm{KBr}$ disk): $3421.72-3448.72 \mathrm{~cm}^{-1}(\mathrm{O}-\mathrm{H})$, $3205.69 \mathrm{~cm}^{-1}$ (N-H, amide), $3005.10 \mathrm{~cm}^{-1}$ (C$\mathrm{H})$, aromatic), $1616.35 \mathrm{~cm}^{-1}(\mathrm{C}=\mathrm{N}), 1527.62-$ $1558.48 \mathrm{~cm}^{-1} \quad(\mathrm{C}=\mathrm{C}$, aromatic $), 1442.75-$ $1481.33 \mathrm{~cm}^{-1}(\mathrm{~N}=\mathrm{N}), 1284.59 \mathrm{~cm}^{-1}(\mathrm{C}-\mathrm{O})$, phenolic) (Fig.7.).

${ }^{1} \mathrm{H}-\mathrm{NMR} \quad\left(\mathrm{CDCl}_{3}-400 \mathrm{MHz}\right) \delta=12.311 \quad(\mathrm{~s}$, $2 \mathrm{H}, \mathrm{OH}), 10.991$ (s, 2H, N-H), 8.952 (s, 2H, $\mathrm{CH}=\mathrm{N}), 7.125-8.758$ (m, $16 \mathrm{H}, \mathrm{Ar}), 2.509$ 3.387 (Organic solvents, DMSO, $\mathrm{H}_{2} \mathrm{O}$ ) (Fig.8.).

Elemental analysis: $\mathrm{C}_{31} \mathrm{H}_{23} \mathrm{~N}_{7} \mathrm{O}_{2}$, Calculated (\%) C: 62.06; H: 4.24; N: 21.44; O: 6.12; S, 6.14. Found (\%) C: 62.11, H: 4.33, N: 21.25, O: $6.17, \mathrm{~S}: 6.14$.

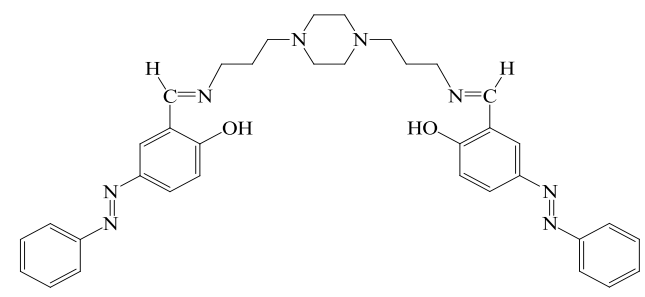

Scheme 2 Azo Schiff base (I)

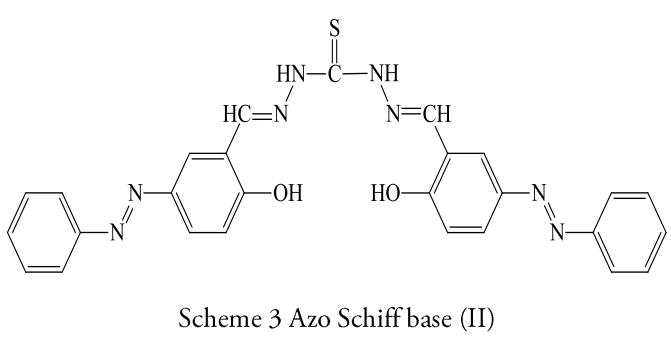

\subsection{BIOLOGICAL ACTIVITY}

The prepared compounds were tested for their antimicrobial activity against four species of bacteria (Bacillus subtilis, Escherichia coli , Staphylococcus aureus, Salmonella typhi) using filter paper disc method [38]. The screened compounds were dissolved individually in DMSO (dimethyl sulfoxide) in order to make up a solution of 50,100 , and $200 \mu \mathrm{g} / \mathrm{ml}$ concentration for each of these compounds. Filter paper discs (Whatman No.1 filter paper, $5 \mathrm{~mm}$ diameter) were saturated with the solution of these compounds. The discs were placed on the surface of solidified Nutrient agar dishes seeded by the tested bacteria. The diameters of inhibition zones $(\mathrm{mm})$ were measured at the end of an incubation period, which was $24 \mathrm{~h}$ at $37^{\circ} \mathrm{C}$ for bacteria. Discs saturated with DMSO are used as solvent control. Ciprofloxacin $100 \mu \mathrm{g} / \mathrm{ml}$ was used as reference substance for bacteria [38].

\section{RESULTS AND DISCUSSION}

\subsection{SYNTHESIS}

The prepared organic compounds (I,II) were synthesized by the condensation of 3-formyl4-hydroxy phenylazo benzene with 1,4-Bis(3aminopropyl) piprazine, Thiocarbohydrazide in the molar ratio 1:2 in absolute ethanol. The reactions proceeded smoothly, producing the corresponding Azo Schiff bases in good yield. The ligands are soluble in common organic solvent but insoluble in water. The structures of the ligand were elucidated by elemental analyses, MS, FTIR, electronic absorption, and $1 \mathrm{H}$ NMR spectra, which help in elucidating their empirical formula (Table 1).

\subsection{ElEMENTAL ANALYSES OF AZO SCHIFF BASES}

The results of elemental analyses Azo Schiff bases are in good agreement with those required by the proposed formula. 


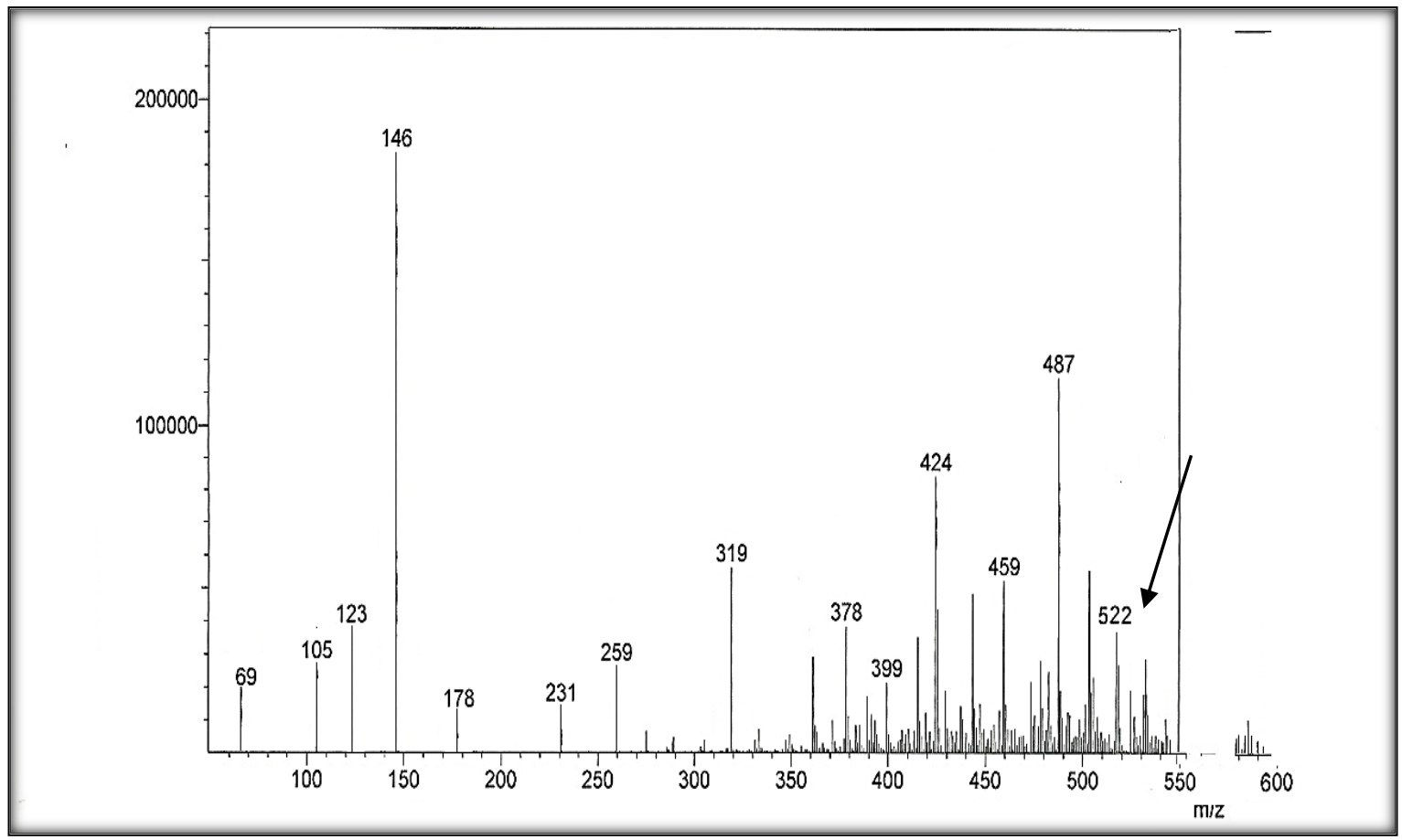

Fig.5. MS spectrum of Azo-Schiff base (II)

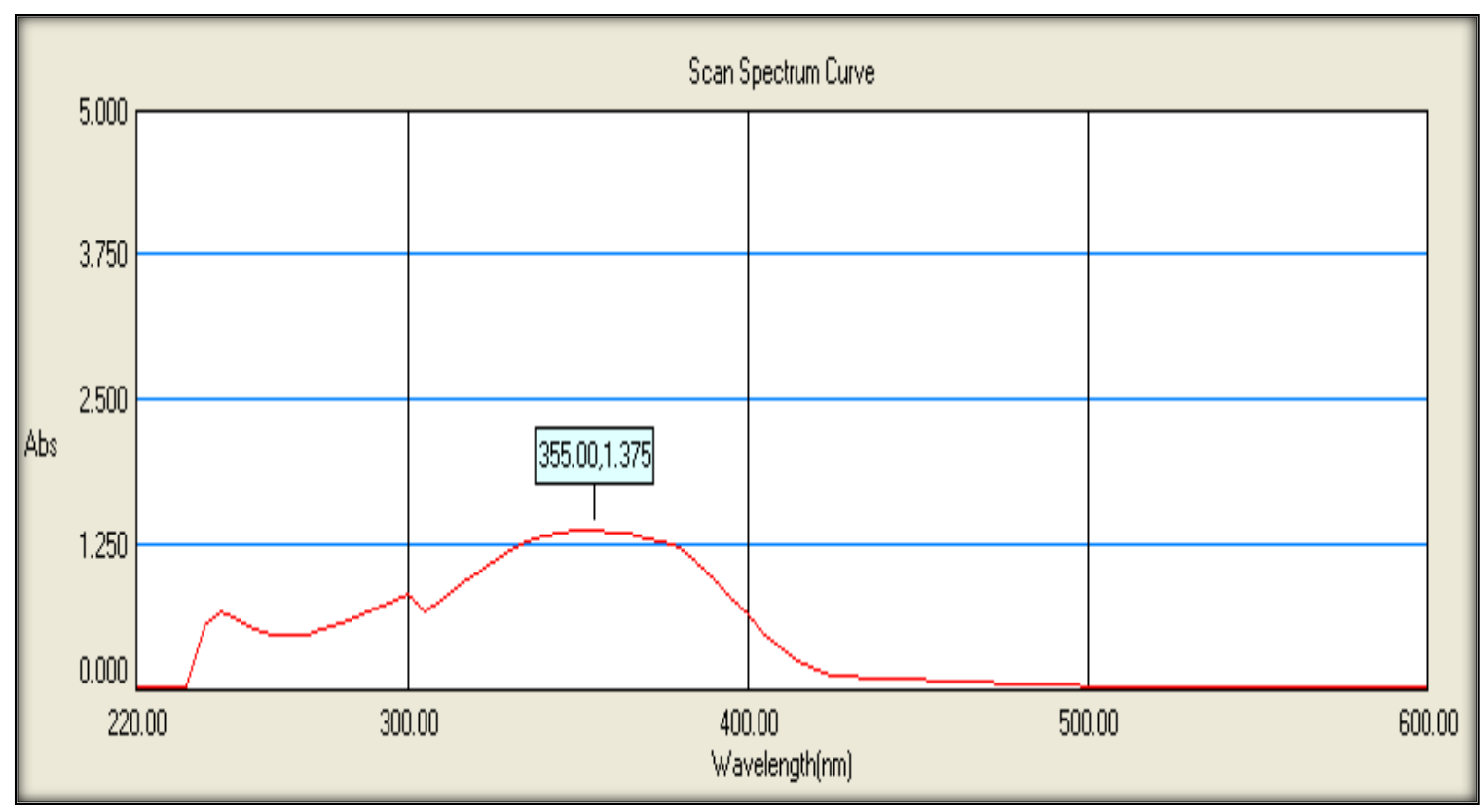

Fig.6. UV spectrum of Azo Schiff base (II) 


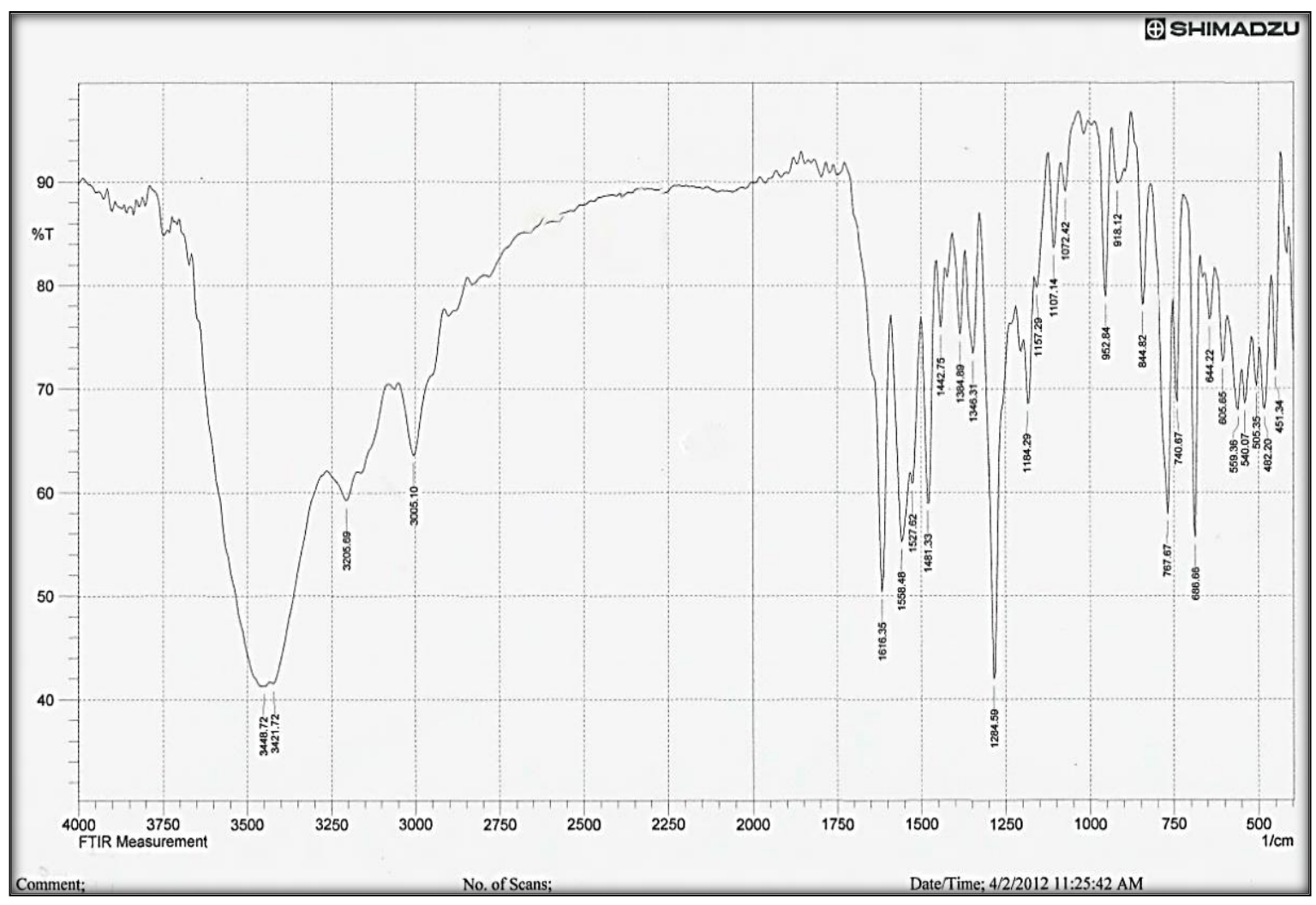

Fig.7. IR spectrum of Azo-Schiff base (II)

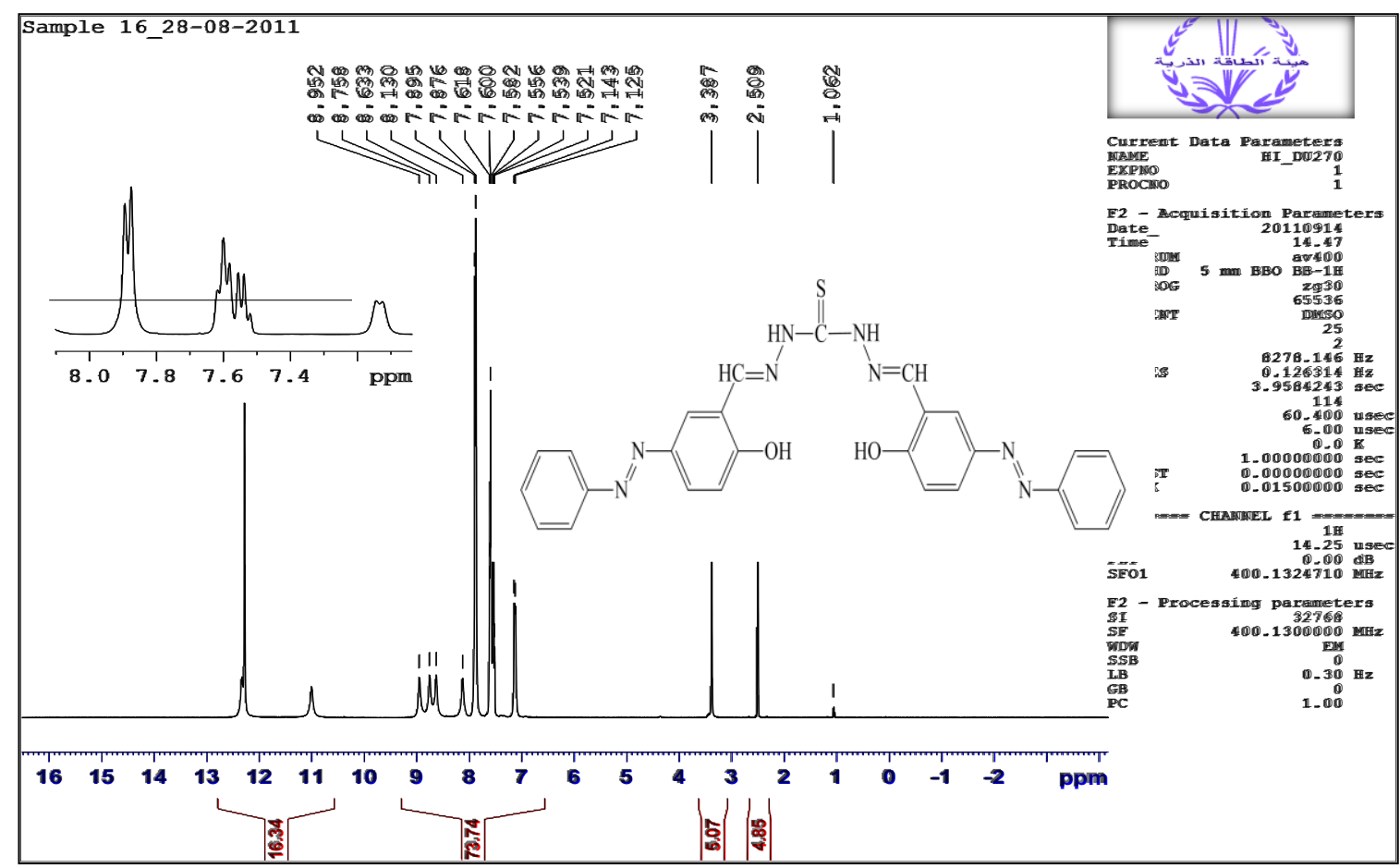

Fig.8. 1HNMR spectrum of Azo-Schiff base (II) 
TABlE 1: COLOR, MOLECULAR WEIGHT, MELTING POINT OF (I, II).

\begin{tabular}{|l|l|l|l|l|l|l|}
\hline $\begin{array}{l}\text { AzoShiff } \\
\text { base }\end{array}$ & Color & M.Wt & $\begin{array}{l}\text { Melting } \\
\text { point }{ }^{\circ} \mathrm{C}\end{array}$ & $\begin{array}{l}\lambda_{\max } \\
\mathrm{nm}\end{array}$ & $\begin{array}{l}\text { Yield } \\
\%\end{array}$ & $\begin{array}{l}\text { Crystallization } \\
\text { Solvent }\end{array}$ \\
\hline I & Orange & 616 & $227-228$ & 355 & $75 \%$ & Dioxan \\
\hline II & Yellow & 522 & 238 & 335 & $75 \%$ & $\begin{array}{l}\text { DMF \&Water } \\
(9: 1)\end{array}$ \\
\hline
\end{tabular}

\subsection{IR SPECTRA}

In the IR spectra the five bands at 1635.64, $1616.35 \mathrm{~cm}^{-1}$ are attributed to imine group $(-\mathrm{HC}=\mathrm{N}-)$ for (I, II) (Fig 3 and 7), respectively. The bands in the spectra at 1585.49, 1527.62 and 1558.48 are due to $(\mathrm{C}=\mathrm{C})$ of aromatic rings. The $v(\mathrm{OH})$ stretching frequencies bands are observed at $3417.86-3475.73$ and $3421.72-3448.72 \mathrm{~cm}^{-1}$ for (I,II), respectively. The IR spectra of (I, II) shows characteristic absorption bands at $1473.62-1496.76$ and $1442.75-1481.33 \mathrm{~cm}^{-1}$ due to $v(\mathrm{~N}=\mathrm{N})$ stretching vibrations, respectively. The bands which observed for all compounds at 1284.59 and $1284.59 \mathrm{~cm}^{-1}$ due to $v(\mathrm{C}-\mathrm{O})$ vibration, while the band at 2812.21-2935.66 $\mathrm{cm}^{-1}$ are attributed to $(\mathrm{C}-\mathrm{H}$ alkanes) for (I). Also, the bands at 3417.863475.73 , and $3421.72-3448.72 \mathrm{~cm}^{-1}$ are attributed to (C-H ar) for (I, II) respectively. However, in the IR spectra of Azo schiff bases this band $(\mathrm{C}=\mathrm{O})$ disappears and a new vibration band for azo methane $\quad(-\mathrm{HC}=\mathrm{N}-)$ is observed at 1635.64 , and $1616.35 \mathrm{~cm}^{-1}$, indicating that complete condensation takes place [39-40].

\subsection{H NMR SPECTRA OF LIGANDS (I, II)}

The $1 \mathrm{H}$ NMR spectra of ( I, II) ligands in DMSO (Fig 4 and 8) shows a singlet signal at 14.28, and $12.311 \mathrm{ppm}$ assigned to the protons of $\mathrm{OH}$ groups of the ligands (I, II) respectively, while the singlet signal at 10.991 ppm assigned to the protons of (CO-NH-) group of the ligand (II). The multiple signals $8.021-7.054$ and $8.758-7.125 \mathrm{ppm}$ are due to the aromatic protons for (I,II) respectively.
The singlet signals at 8.449 and $8.952 \mathrm{ppm}$ are due to the $2 \mathrm{H},(\mathrm{HC}=\mathrm{N})$ protons of the ligand (I,II) respectively.

The other obtained values for ${ }^{1} \mathrm{H}$ NMR chemical shifts of these compounds are given in the experimental section. These data are in agreement with those previously reported for similar compounds. These results strongly suggest that the proposed compounds have been formed [39-40].

\subsection{MASS SPECTRA OF LIGANDS (I,II)}

The compound (I) show peaks at 616 and many fragments at: 146, 176, 259, 321, 361, 492 and 575. Compound (II) show peak at 522 and many fragments at: 69, 105, 123, 146, 178, 399, 424, 487, 522 respectively.

\subsection{BIOLOGICAL ACTIVITY}

During the last two or three decades, attention has been increasing due to the synthesis of Azo Schiff bases which exhibits various biological activities including antibacterial, fungicidal, tuberculostatic and plant growth regulative properties [41]. It was judicious to investigate the synthesis of various new types of Azo Schiff bases and studied their antibacterial activity against four strains of bacteria (Bacillus subtilis, Escherichia coli, Staphylococcus aureus, and Salmonella typhi) (Fig. 9.).

The concentrations used for the screened compounds are 50, 100, and $200 \mu \mathrm{g} / \mathrm{ml}$. Ciprofloxacin was used as reference standard while DMSO as control and inhibition zones are measured in $\mathrm{mm}$. The new compounds were tested against one strain each of a gram positive and two gram negative. The test results are presented in Table 2 .

All compounds were not active when used in the range between $50,100 \mu \mathrm{g} / \mathrm{ml}$ but were active in the concentrations $200 \mu \mathrm{g} / \mathrm{ml}$. 
TABLE 2: EFFECT OF NEW AZO SCHIFF BASES ON THE GROWTH OF TESTED BACTERIA (CONC.200 MG/ML)

\begin{tabular}{|c|c|c|c|c|}
\hline \multirow{3}{*}{ AzoShiff base } & \multicolumn{4}{|c|}{ Bacteria } \\
\hline & \multicolumn{2}{|c|}{ Gram negative } & \multicolumn{2}{|c|}{ Gram positive } \\
\hline & B. subtilis & S. aureus & E.coli & S. typhi \\
\hline I & $19 \mathrm{~mm}$ & $16 \mathrm{~mm}$ & $15 \mathrm{~mm}$ & $18 \quad \mathrm{~mm}$ \\
\hline II & $20 \mathrm{~mm}$ & $18 \mathrm{~mm}$ & $16 \mathrm{~mm}$ & $14 \quad \mathrm{~mm}$ \\
\hline Control & $00 \mathrm{~mm}$ & $00 \mathrm{~mm}$ & $00 \mathrm{~mm}$ & $00 \mathrm{~mm}$ \\
\hline Ciprofloxacin & $20 \mathrm{~mm}$ & $20 \mathrm{~mm}$ & $20 \mathrm{~mm}$ & $20 \mathrm{~mm}$ \\
\hline
\end{tabular}

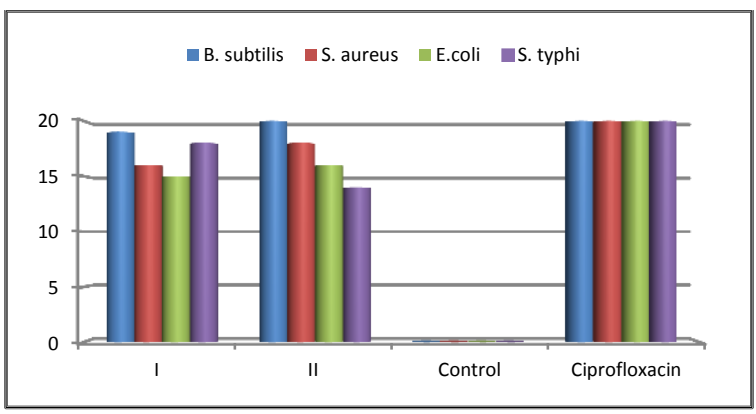

Fig.9. Antibactial activity (Gram positive, negative) of synthesized compounds

\section{THERMAL STUDIES}

Thermogravimetric (TG) analyses for the ligands were carried out within the temperature range from ambient temperature up to $900^{\circ} \mathrm{C}$. The thermal behaviour of the ligands show good agreement with the formula suggested from the analytical data in table 3. The ligands (I, II) undergo two step decomposition processes (Fig. 10.). The first step of ligand (I) was started at $197^{\circ} \mathrm{C}$ to $210{ }^{\circ} \mathrm{C}$ show mass loss $2.283 \%$ (calcd. $2.922 \%$ ), was attributed to the loss of water moiety while the first step of ligand (II) was started at $220^{\circ} \mathrm{C}$ to $330^{\circ} \mathrm{C}$ show mass loss $35.941 \%$ (calcd. 35.809\%), This was attributed to the loss of $\left[\mathrm{C}_{6} \mathrm{H}_{8} \mathrm{~N}_{4} \mathrm{O} .2 \mathrm{H}_{2} \mathrm{O}\right]$ moiety. The second step of ligand (I) was started at $300^{\circ} \mathrm{C}$ to $450^{\circ} \mathrm{C}$ show mass loss $28.203 \%$ (calcd. 28.085\%), This was attributed to the loss of $\left.\left[\mathrm{C}_{7} \mathrm{H}_{11} \mathrm{~N}_{5}\right) \cdot \mathrm{H}_{2} \mathrm{O}\right]$ moiety. The second step of ligand (II) was started at $390^{\circ} \mathrm{C}$ to $665^{\circ} \mathrm{C}$ show mass loss
$68.006 \%$ (calcd. $68 \%$ ). This was attributed to the loss of $\left[\mathrm{C}_{24} \mathrm{H}_{11} \mathrm{~N}_{3} \mathrm{O}\right]$ moiety. Also the third step of ligand (I) was started at $450^{\circ} \mathrm{C}$ to $730^{\circ} \mathrm{C}$ show mass loss $72.24 \%$ (calcd. $71.1 \%$ ). This was attributed to the loss of $\left[\mathrm{C}_{28} \mathrm{H}_{9} \mathrm{~N}_{3} \mathrm{O}_{2}\right]$ moiety.

\section{KINETIC STUDY}

The kinetic analysis parameters such as activation energy $\left(\Delta \mathrm{E}^{*}\right)$, enthalpy of activation $\left(\Delta \mathrm{H}^{*}\right)$, entropy of activation $\left(\Delta \mathrm{S}^{*}\right)$, free energy change of decomposition $\left(\Delta \mathrm{G}^{*}\right)$ were evaluated graphically by employing the Coats-Redfern relation [42].

$\log [-\log (1-\alpha) / \mathrm{T} 2]=\log \left[\mathrm{AR} / \theta \mathrm{E}^{*}\left(1-2 \mathrm{RT} / \mathrm{E}^{*}\right]\right.$ $-\mathrm{E}^{*} / 2.303 \mathrm{RT}$ where $\alpha$ is the mass loss up to the temperature $\mathrm{T}, \mathrm{R}$ the gas constant, $\mathrm{E}^{*}$ the activation energy in $\mathrm{Jmol}^{-1}, \theta$ the linear heating rate and $\left(1-2 \mathrm{RT} / \mathrm{E}^{*}\right) \approx 1$. A plot of left hand side of Eq. (1) against $1 / \mathrm{T}$ gives aslope from which $\mathrm{E}^{*}$ was calculated and A (Arrhenius constant) was determined from the intercept.

From relevant data, linearization plots (Figure 11-13) confirm first order kinetics. The entropy of activation $\left(\Delta S^{*}\right)$ and the free energy change of activation $\left(\Delta \mathrm{G}^{*}\right)$ were calculated using equations (2) and (3):

$\Delta \mathrm{S}^{*}(\mathrm{JK}-1 \mathrm{~mol}-1)=2.303 \mathrm{R}[\log (\mathrm{Ah} / \mathrm{kT})$

$\Delta \mathrm{G}^{*}(\mathrm{Jmol}-1)=\Delta \mathrm{H}^{*}-\mathrm{T} \Delta \mathrm{S}^{*}$

where $\mathrm{k}$ and $\mathrm{h}$ are the Boltzman and Plank constant, respectively. The calculated values of $\Delta \mathrm{E}^{*}, A, \Delta \mathrm{S}^{*}$ and $\Delta \mathrm{G}^{*}$ for the decomposition steps of the ligands are given in Table 4. According to the kinetic data obtained from the TG curves, all the ligands 


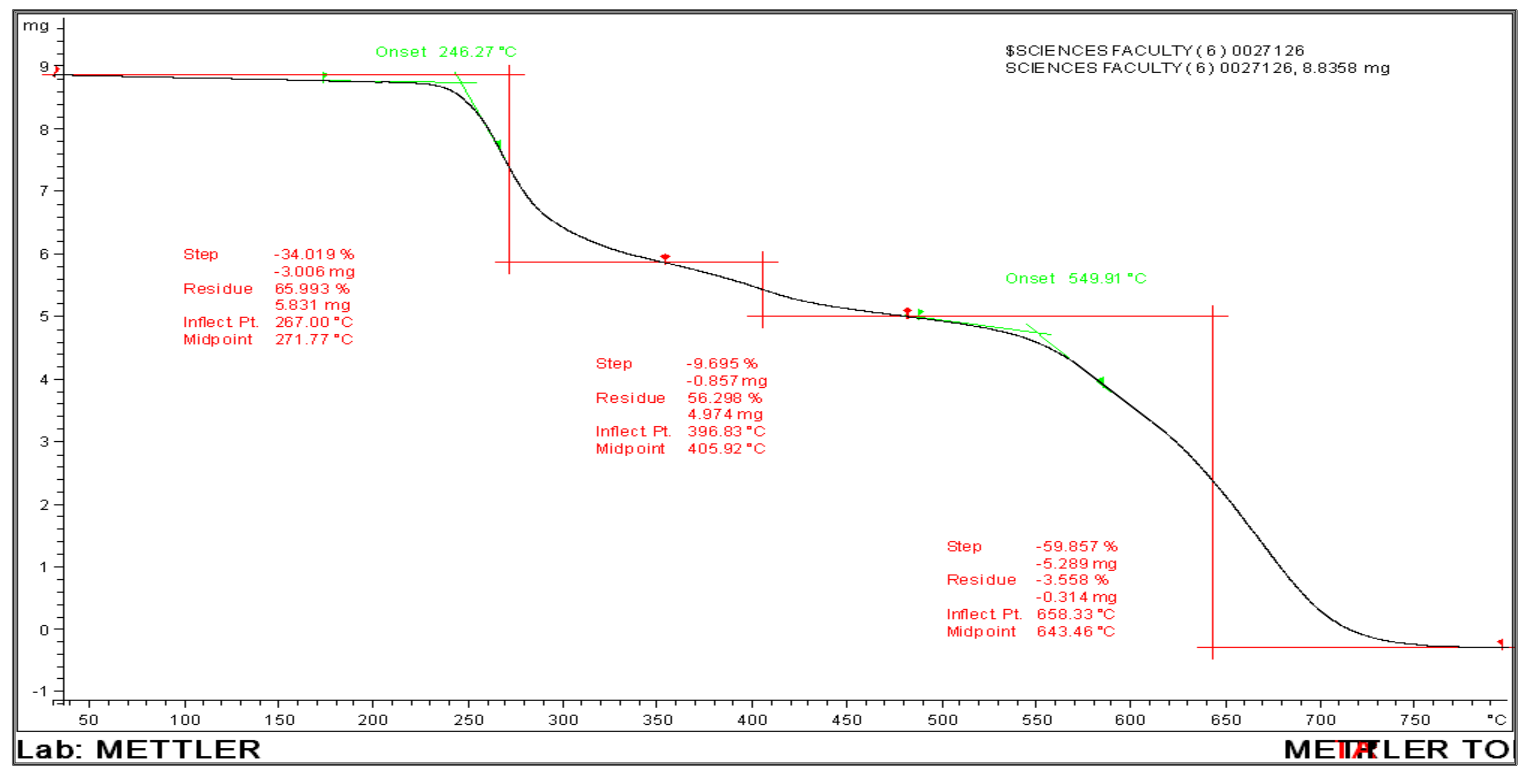

(I)

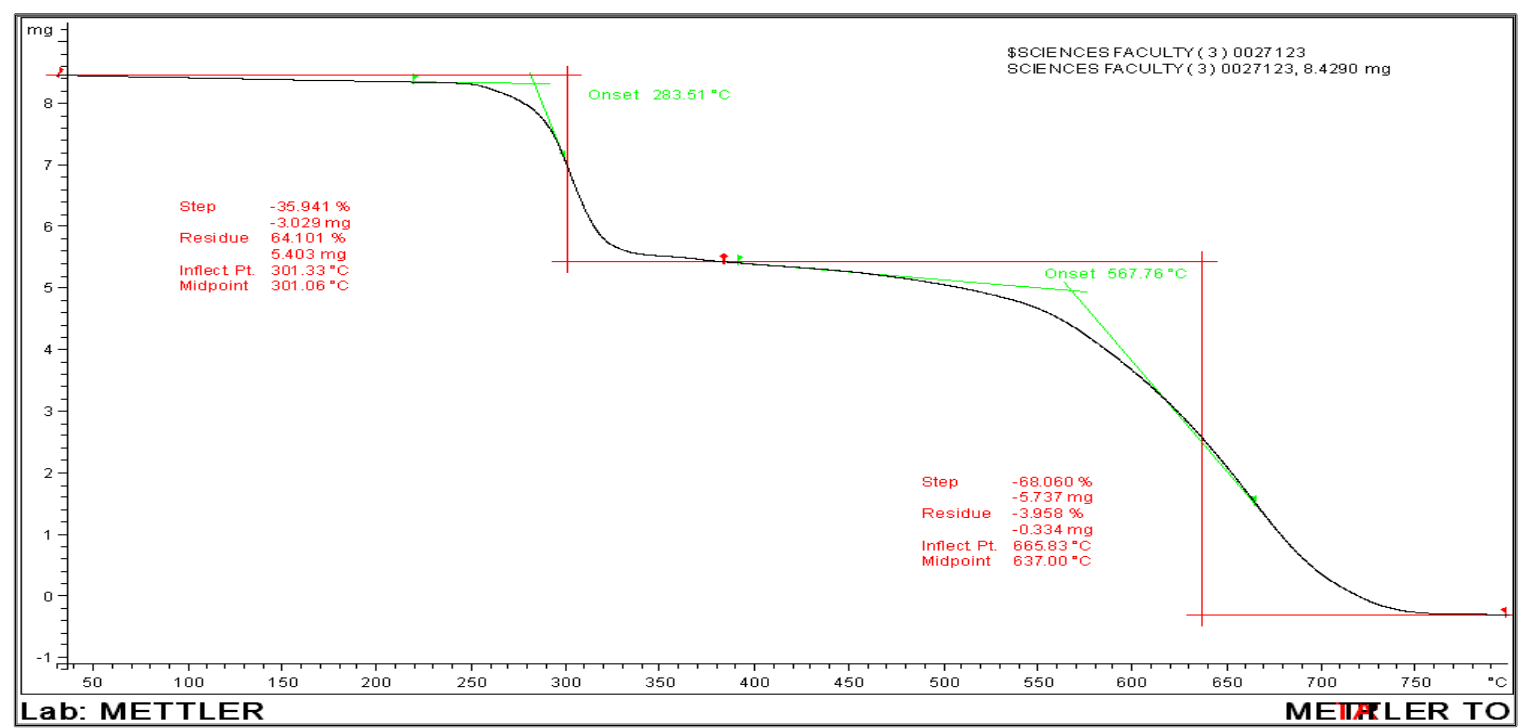

(II)

Fig.10. TG curve of ligand (I) and (II)

TABLE 3: THERMO ANALYTICAL DATA OF AZO-SHIFF BASES

\begin{tabular}{|c|c|c|c|c|c|c|}
\hline Ligands & steps & $\begin{array}{l}\mathrm{T}_{\mathrm{i}} \\
{ }^{0} \mathrm{C}\end{array}$ & $\begin{array}{l}\mathrm{T}_{\mathrm{f}} \\
{ }^{0} \mathrm{C}\end{array}$ & $\mathrm{T}_{\max }{ }^{0} \mathrm{C}$ & $\begin{array}{l}\quad \Delta \mathbf{m} \% \\
\text { Found } \\
\text { (cal.) }\end{array}$ & Assignment \\
\hline \multirow{4}{*}{ I } & 1 & 197 & 210 & 207.83 & $2.283(2.922)$ & $-\left[\mathrm{H}_{2} \mathrm{O}\right]$ \\
\hline & 2 & 300 & 450 & 377.02 & $28.203(28.085)$ & $-\left[\mathrm{C}_{7} \mathrm{H}_{11} \mathrm{~N}_{5}\right) \cdot \mathrm{H}_{2} \mathrm{O}$ \\
\hline & 3 & 450 & 730 & 646.60 & $\begin{array}{l}72.24 \% \\
(71.1)\end{array}$ & {$\left[\mathrm{C}_{28} \mathrm{H}_{9} \mathrm{~N}_{3} \mathrm{O}_{2}\right]$} \\
\hline & \multicolumn{6}{|c|}{ final residue:(found: $2.702 \%)$, [Calc (2.597\%) ]. } \\
\hline \multirow{3}{*}{ II } & 1 & 220 & 330 & 326.92 & $\begin{array}{l}35.941 \\
(35.809)\end{array}$ & $-\left[\mathrm{C}_{6} \mathrm{H}_{8} \mathrm{~N}_{4} \mathrm{O} .2 \mathrm{H}_{2} \mathrm{O}\right]$ \\
\hline & 2 & 365 & 700 & 460.18 & $\begin{array}{c}68.006 \\
(68)\end{array}$ & $-\left[\mathrm{C}_{24} \mathrm{H}_{11} \mathrm{~N}_{3} \mathrm{O}\right]$ \\
\hline & \multicolumn{6}{|c|}{ final residue:(found: $3.958 \%$ ), [Calc (3.834\%) ]. } \\
\hline
\end{tabular}


TABLE 4: THERMODYNAMIC ACTIVATION PARAMETERS OFAZO-SHIFF BASES

\begin{tabular}{|c|c|c|c|c|c|c|c|c|}
\hline Ligands & $\begin{array}{l}\text { Order } \\
\text { n }\end{array}$ & steps & $\mathrm{R}^{2}$ & $\begin{array}{l}A \\
s^{-1}\end{array}$ & $\begin{array}{l}\mathrm{E}_{\alpha} \\
\mathrm{kJ} \cdot \mathrm{mol}^{-1}\end{array}$ & $\begin{array}{l}\Delta \mathrm{S}^{*} \\
\mathrm{~J} . \mathrm{K}^{-1} \mathrm{~mol}^{-1}\end{array}$ & $\begin{array}{l}\Delta \mathrm{H}^{*} \\
\mathrm{~kJ} \cdot \mathrm{mol}^{-1}\end{array}$ & $\begin{array}{l}\Delta \mathrm{G}^{*} \\
\mathrm{~kJ} . \mathrm{mol}^{-1}\end{array}$ \\
\hline \multirow{3}{*}{ I } & 1 & 1 & 0.985 & $1.5 \times 10^{-4}$ & 23.71 & -321.9 & 19.72 & 174.52 \\
\hline & 1 & 2 & 0.989 & 258.69 & 98.17 & -205.2 & 92.77 & 226.16 \\
\hline & 1 & 3 & 0.999 & $3.7 \times 10^{-6}$ & -10.14 & -358.3 & -17.78 & 311.69 \\
\hline \multirow[b]{2}{*}{ II } & 1 & 1 & 0.96 & 17.27 & 72.19 & -226.4 & 67.57 & 193.57 \\
\hline & 1 & 2 & 0.99 & $3.3 \times 10^{-6}$ & -10.99 & -358.4 & -17.97 & 283.36 \\
\hline
\end{tabular}

have negative entropy, which indicates that the ligands are formed spontaneously. The values of the activation energy in the Table 4, we find that the activation energy of the second step of the disintegration associated with (I) is larger than activation energies for the first step, and this indicates that the rate of decomposition in the second step is less than the rate of decomposition in the first step. This is due to residual hardness of ligand structure, which requires a higher power to restore order and organization before any change in the composition and vice versa As the negative values of the energies of activation is energy-extensive the resistance solid inside the body that lead to the spread of heat [43]. Also we find that the positive values for $\left(\Delta \mathrm{G}^{*}\right)$ to indicate that the nonspontaneous reactions when changing situation. The negative values for $\left(\Delta S^{*}\right)$ indicate that the union has more ordered structure of the reactants and the reactions are slow more than the natural or formal. While positive values for $\left(\Delta \mathrm{H}^{*}\right) \mathrm{s}$ indicate that the endothermic reactions. And negative values indicate that the exothermic reactions and small values for (Arrhenius constant)(A) shows that the dissociation reactions for quick ligand while large and positive values when the case of the transition can be classified as slow reactions [44].

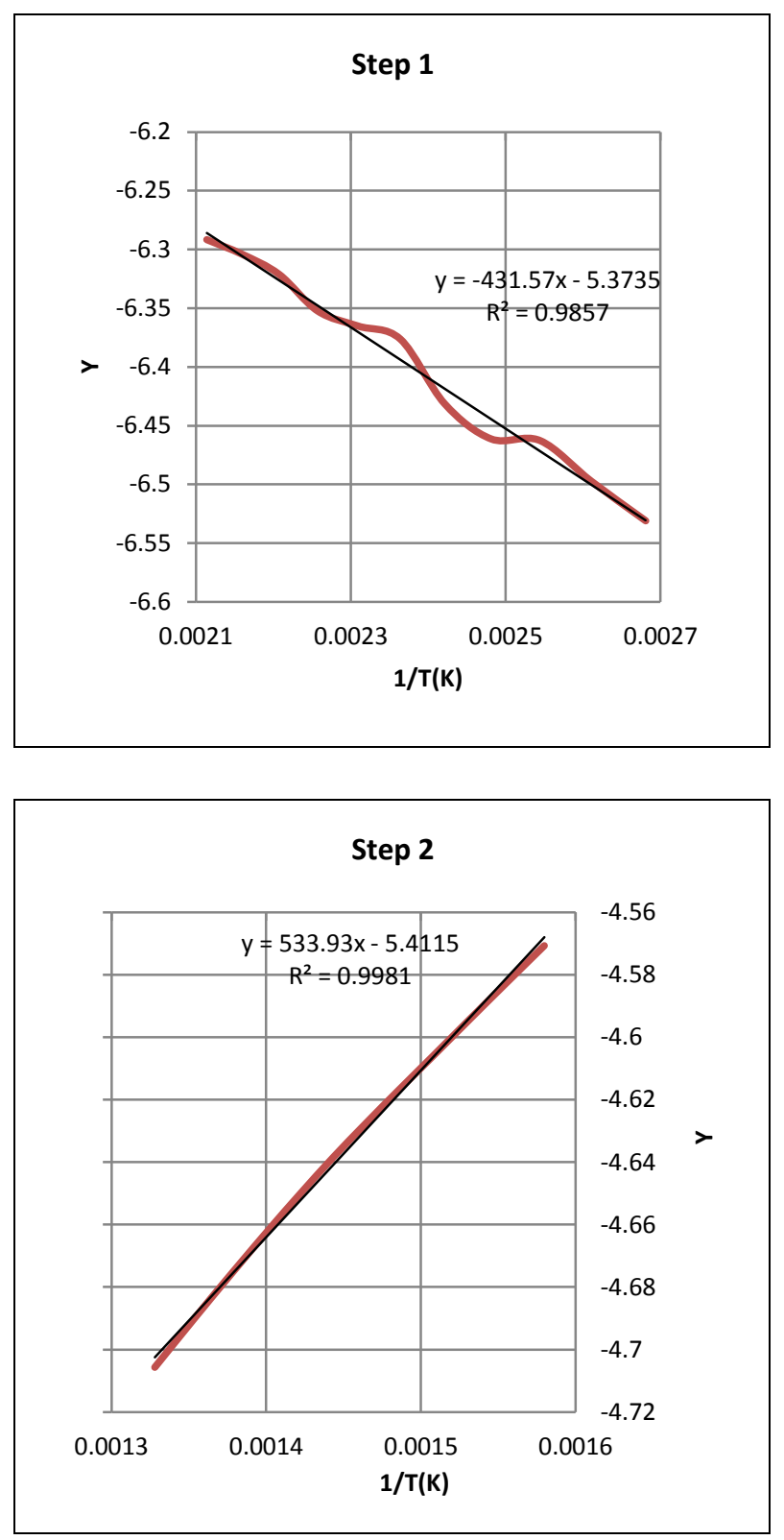

Fig.11. Linearization plot of ligand (I) when $\mathrm{Y}=\log \left[\frac{1-(1-\alpha)^{1-\mathrm{n}}}{\mathrm{T}^{2}(1-\mathrm{n})}\right] \quad$ for $\mathrm{n} \neq 1$ 


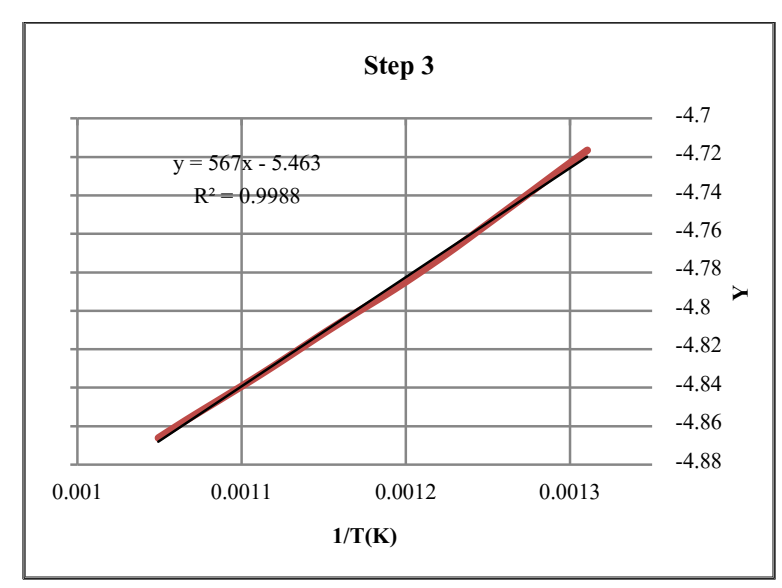

Fig.12. Linearization plot of ligand (I) when $\mathrm{Y}=\log \left[\frac{1-(1-\alpha)^{1-\mathrm{n}}}{\mathrm{T}^{2}(1-\mathrm{n})}\right] \quad$ for $\mathrm{n} \neq 1$
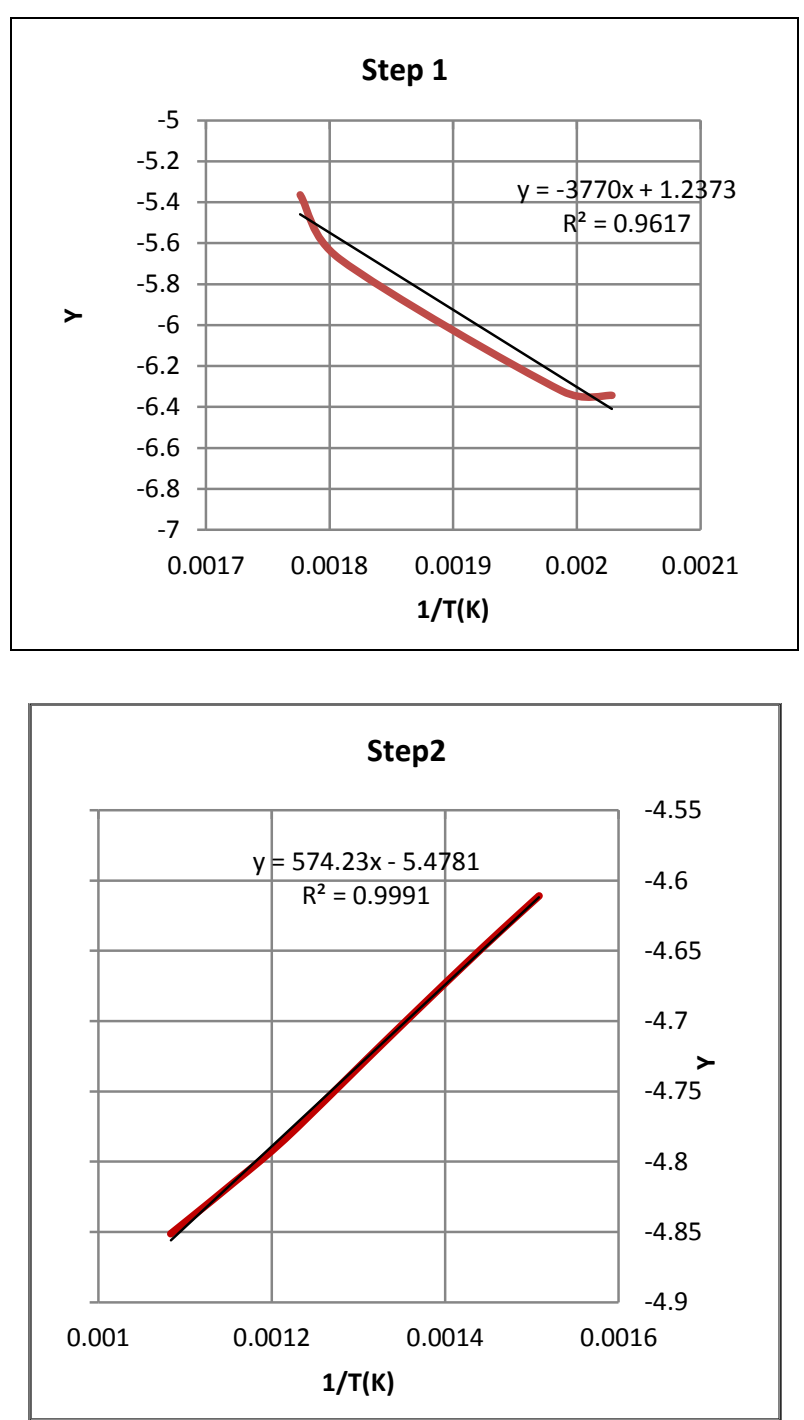

Fig.13. Linearization plot of ligand (II) when $\mathrm{Y}=\log \left[\frac{1-(1-\alpha)^{1-\mathrm{n}}}{\mathrm{T}^{2}(1-\mathrm{n})}\right] \quad$ for $\mathrm{n} \neq 1$

\section{CONCLUSION}

1- The (I, II) compounds are new and were prepared for the first time.

2- The new compounds were identified by 1HNMR, IR, LC-MS spectral methods.

3-Some of the prepared compounds have been biologically screened i.e. studying their effects against two gram-positive, two gramnegative bacteria. The results show that their activities were found to vary from moderate to very strong.

4- The thermal degradation behavior and thermal stability of the ligands (I, II) are discussed. The thermodynamic parameters of decomposition processes of Ligands, namely, activation energy $(\mathrm{E} \alpha)$, enthalpy change $\left(\Delta \mathrm{H}^{*}\right)$, entropy change $\left(\Delta \mathrm{S}^{*}\right)$, and Gibbs free energy change $\left(\Delta G^{*}\right)$ were evaluated graphically by employing the Coats-Redfern method.

\section{ACKNOWLEDGMENT}

The authors are grateful to the Department of Chemistry, Faculty of Science, University of Damascus, Damascus, Syria for supporting of this paper.

\section{REFERENCES}

[1] Pandey, V.K., and Negi, H.S.,"Synthesis and Antimicrobial Activity of Some New Formazan Derivatives". Indian Drugs, 36(1), 37, 1999.

[2] Morrison and Boyed, "Organic Chemistry", 6th Ed. , 1996.

[3] Cimerman, Z., Milijanic, S., and Galic, N., "Schiff Bases Derived from Amino Pyridines asSpectroflourimetric Analytical Reagents". CroaticaChemicaActa, 73(1), 81-95, 2000.

[4] Venturini, A., and Gonzalez, J., "Staudinger Reduction", J. Org. Chem., 67, 9089-9092 , 2002.

[5] RAMAN, N., Pitchaikani, Y., and Kulandaisamy, A., "Synthesis and Characterization of $\mathrm{cu}(\mathrm{II})$, $\mathrm{Ni}(\mathrm{II}), \mathrm{Zn}(\mathrm{II})$ and $\mathrm{VO}$ (II) Schiff base complexes derived from ophenylenediamine and 
acetoactanilide". Proc. Indian Acad. Sci., 113(3), 183-189, 2001.

[6] Garg, H.G., and Kauv, M.S., "Synthesis of benzyaldehyde substituted phenyl carbonyl hydrazones". J. Med. Chem., 15, 554 , 1992.

[7] Sharma, K.P., Jolly, V.S., Phatak, P., "Schiff bases and their derivatives as potential anticancer agents", Ultra Scient. Phys. Sci., 10, 263-266, 1998.

[8] Jarrahpour, A.A., and Zarei, M., "Synthesis of (3,4-bis\{[2-hydroxy-3-methoxy- -(4methylphenylazo) benzylidene]-amino\}penyl) phenyl methanone as a novel azo Schiff base". Molnank, M 376, 1-3, 2004.

[9] Muhammed, I., Javed, I., Shahid, I., and Nazia, I., "In Vitro Antibacterial Studies of Ciprofloxacinimines and their Complexes with $\mathrm{Cu}(\mathrm{II}), \mathrm{Ni}(\mathrm{II})$, Co(II) and Zn(II)". Turk. J. Biol., 31, 67-72, 2007.

[10] Vashi, K., and Naik, H.B. "Synthesis of Novel Schiff base and Azetidinone Derivatives and Their Antibacterial Activity". Eur. J. Chem., (1), 272-276, 2004.

[11] Mone, P., Bhalvankar, R., and Pattar, S., "Synthesis of Some Iimes and Investigation of Their Biological Activity". J. Indian Chem., 78, 474-475, 2001.

[12] Vaghasiya, Y.K., Nairi, R.S., Baluja, M., Chonda, S.S., "Synthesis, Structural Determination and Antibacterial Activity of Compounds Derived From Vasaillin and 4-Amino antipyrine". J. Scrt. Chem. Soc., 69, 991-998, 2004.

[13] Mtrei, R., Yadawe, M., and Patil, S.A., "Synthesis of Biological Active p-bis(amino-5-mercapto1,2,4-triazole-3-yl)benzene and its Schiff base: a new class of bistriazole". Orient. J. Chem., (12), 101-102, 1996.

[14] Hussain, M.E., Allam, M.V., Begum, J. Akbar, M.A., Hddin, M.N., Smith, F.E., and Hynes, R.C., "The Preparation, Characterization, Crystal and Biological Activities of Some $\mathrm{Cu}(\mathrm{II})$ Complexes of the 2-benzoyl pyridine Schiff bases of 5-methyl and 5-benzyldithio carbazate". Inorg. Chem. Acta., 249, 207-213, 1996.

[15] Phatok, P., Jolly, V.S., and Sharma, K.P., "Synthesis and Biological Activities of Some New Substituted anylazo Schiff base". Orient. J. Chem., 16, 493-494, 2000.

[16] Olcay, B., and Hakan, B., "Synthesis of Schiff and Mannich Bases of IsatinDeivatives with 4-
Amino-4,5-Dihydro-1H-1,2,4-Triazole-5- Cues". Molecules, 13, 2126-2135, 2008.

[17] Pandeya, S.N., Sriram, D., Declercq,E., and Nath, G. "Synthesis, antibacterial, antifungal and antiHIV activities of Schiff and Mannich bases derived from isatin derivatives and (N-[4-(4)Chloro phenyl)thiazol-2-yl] thiosemicarbazide".Eur. J. Pharm. Sci., (9), 25-31, 1991.

[18] Jarraphour, A., and Zare, M."Synthesis of novel azo Schiff base bis[5-(4-methoxyphenylazo)-2hudroxy-3-methoxybenzaldehde]-1,2-phenylene diamine". Molbank,M 377, 1-3, 2004.

[19] Jarraphour, A., Motamedifar, M., Pakshir, K., Hadi, N., and Zarei,M., "Synthesis of Novel Azo Schiff Bases and Their ntibacterial and Antifungal Activites". Molecules,9, 815-824, 2004.

[20] K. Nejati, Z. Rezvani and B. Massoumi, ScienceDirect, 2007, 75, 653.

[21] H. Rolla and O. Mermut, J. Pure Appl. Chem. , 76, 1445, 2004.

[22] Iranpoor, N., Firouzabadi, H., Khalili, D. \&Motevalli, S., Easily prepared azopyridines as potent and recyclable reagents for facile esterification reactions: an efficient modified Mitsunobu reaction. J. Org. Chem., 73, 48824887, 2008.

[23] Antonov, L. M., Kurteva, V. B., Simeonov, S. P.,Deneva, V. V., Crochet, A. \& Fromm, K. M. Tautocrowns: a concept for a sensing molecule withan active side-arm. Tetrahedron, 66, 42924297, 2010.

[24] Park, J. \&Koh, J. . The synthesis and spectral properties of an encapsulated aminoazobenzene dye. Dyes Pigm., 82, 347-352, 2009.

[25] Zollinger, H. . Diazo Chemistry I, VCH, Weinheim, 1994.

[26] Ylldiz, E. \&Boztepe, H. . Synthesis of Novel Acidic Mono Azo Dyes and an Investigation of Their Use in the Textile Industry. Turk. J. Chem., 26, 897-903, 2002.

[27] Jarrahpour, A. \&Alvand, P. . Synthesis of some new sugar based 3,3-disubstituted monocyclic _lactams by asymmetric $[2+2]$ cycloaddition reactions. Iran. J. Sci. Technol. Trans. A-Sci. 31, 17-22, 2007.

[28] Jarrahpour, A. \&Zarei, M. . Efficient onepotsynthesis of 2-azetidinones from acetic 
acidderivatives and imines using methoxymethylene-N,N-dimethyliminium salt. Tetrahedron, 66, 5017-5023, 2010.

[29] Jarrahpour, A. \&Zarei, M.. DMF-dimethyl sulfate as a new reagent for the synthesis of Slactams. Tetrahedron Lett., 50, 1568-1570, 2009.

[30] Zarei, M. \&Mohamadzadeh, M. . 3-Thiolated 2azetidinones: synthesis and in vitroantibacterial and antifungal activities. Tetrahedron,67, 58325840, 2001.

[31] Jarrahpour, A. \&Zarei, M. . The Vilsmeier reagent: a useful and versatile reagent for thesynthesis of 2-azetidinones. Tetrahedron, 65, 2927-2934, 2009.

[32] A. S. Zidan, A. I. El-Said, M. S. El-Meligy, A. A. Aly and O. F. Mohammed, J. Therm. Anal., 62, 665, 2000.

[33] M. F. Abo El-Ghar, N. T. Abdel-Ghani, Y. Badr and O. M. El-Borady, Science and Technology Vision, 3, 58, 2007.

[34] H. H. M. Al-Hmedawi, "Synthesis and Characterization of Transition Metal Chelates of Schiff-bases Derivatives of Expected Biological Activity", M.Sc. Thesis, The University of Baghdad, 2003.

[35] [56] Jarrahpour, A. A., Motamedifar, M., Pakshir, K., Hadi, N. \&Zarei, M. . Synthesis of novel azo Schiff bases and their antibacterial and antifungalactivities. Molecules, 9, 815-824, 2004.

[36] Dinçaple H, Toker F, Durucasu I, Avcibas s, Icli S. New thiophene-based azo ligands containingazomethine group in the main chain for the determination of copper(II) ions. Dyes Pigm,75:11e24, 2007.

[37] Khanmohammadi H, Darvishpour M. New azo ligands containing azomethine groups in the pyridazine-based chain: synthesis and characterization. Dyes Pigm, 81:167e73, 2009.

[38] Ibrahim.U.H.,Basaran.I.,Kilic.T.,Cakir. U., Synthesis, complexation and Anti- fungal, antibacterial activitystudies of a new Macrocyclic SchiffBase,J. Hetrocyclic Chem.,43,1679, 2006.

[39] Pathak, P., Jolly, V. S. \& Sharma, K. P. .Synthesis and biological activities of some new substituted arylazo Schiff bases. Orient. J. Chem., 16, 161-162, 2000.

[40] Rajaa, A.G., "Preparation of Some New AzoSchiff Bases Compounds and Studing Their
Biological Activity". M.Sc. Thesis, College of education for Women, University of Kufa, 2008.

[41] Jarraphour, A., Motamedifar, M.,Pakshir, K., Hadi, N., and Zarei, M., "Synthesis of Novel Azo Schiff Bases and Their Antibacterial andAntifungal Activites". Molecules, 9, 815-824 2004.

[42] B.K. Singh, R.K. Sharma, B.S. Garg, Kinetics and molecular modeling of biologically active glutathione complexes with lead(II)ions, J. Therm. Anal. Calorim.84, 593-600, 2006.

[43] K. Hauffe, Reaktionen in und fasten Stoffen., Izdatel'stvoInostrannayaLiteratura, Moscow pag 74, 1963.

[44] A.W. Coats and J.P. Redfern, Kinetic parameters from thermogravimetric data, Nature, 201(4914):68-69, 1964. 


\title{
تحضير ودراسات طيفية , حركية, التحلل الحرارى و مضادات الميكروبات لقواعد الازوشيف
}

\author{
حامد حسين عيسى \\ جامعة حجا، اليمن
}

الملخص:

في هذا البحث تم التركيز على تحضير وتمييز بعض قو اعد الأزو شيف و المحضرة من تكثيف ب -فورميل عـ ـ هيدروكسى فينيليزو البنزين مع كلا من ا,؛ باى (كأمينو بروبيل ) بييرازين و ثيو كاربو هيدرازيد على التو الي. تم دراسه قو اعد الأزو شيف (IR ،1H- NMR ،GC-MS ،LC-MS) باستخدام تقنية الأطياف تم در اسه نشاط قواعد الأزو شيف كمو اد مضاده للجر اثيم (العضوية الرقيقة والككورات العنقودية الذهبية) و اثبت الدراسه انها موجبه الجرام وأن (السالمونيلا التيفية وكولاي) هي سلبية الجرام أظهر البحث أن يجند الازو له نشاطا متغير ا قادر اعلى تثبيط نمو البكتيريا وقد تعرضت قواعد الأزو شيف للتحليل الحراري المتزامن وتم در اسه آلية التحلل والاستقرار الحراري. 